\title{
AGRONOMIC EFFICIENCY FOR NITROGEN, PHOSPHORUS, AND POTASSIUM IN BEAN CULTIVARS
}

\author{
EFICIÊNCIA AGRONÔMICA PARA NITROGÊNIO, FÓSFORO E POTÁSSIO EM \\ CULTIVARES DE FEIJÃO
}

\author{
Jéssica Schroder PACHECO ${ }^{1}$; Cecília Leão Pereira RESENDE ${ }^{1}$; Rafael Correia MENDES ${ }^{2}$; \\ Helton Santos PEREIRA ${ }^{3}$; Fabricio RODRIGUES ${ }^{1}$ \\ 1. Postgraduate Program in Crop Production, in State University of Goiás, Ipameri, GO, Brazil; 2. Agronomist Engineer in State \\ University of Goiás, Ipameri, GO, Brazil; 3. Embrapa Rice and Beans, Santo Antônio de Goiás, GO, Brazil;
}

\begin{abstract}
The aim of this study was to identify and categorize new bean cultivars regarding their efficiency and responsiveness to nitrogen, phosphorus, and potassium, both individually and simultaneously, as well as to stipulate the cultivars that would suit each niche market based on this classification. Three experiments were conducted in the field separated by nutrients adopting the randomized block design in a factorial scheme $(11 \times 4)$ of 11 cultivars in four doses with three replications. Grain yield was the variable investigated and the means were the basis for the classification separated by in four availabilities: low, partial, adequate dose, and nutritional excess. Genetic variability was observed among the bean cultivars for efficiency and responsiveness (agronomic efficiency) to nitrogen, phosphorus, and potassium. The following cultivars: BRS Agreste, BRS Estilo, BRS Notável, and Pérola revealed the greatest values of efficiency and responsive ratings for nitrogen, phosphorus, and potassium, with indications for low and high technological levels. On the contrary, the cultivars BRS Ametista and BRS Sublime based on the efficiency and non-responsive classification showed a low ability to acquire or utilize the nutrients for grain formation. The BRS Pontal cultivar for all three nutrients displayed a high degree of efficiency with a value exceeding the average under different conditions of stress, suggesting that a more rustic cultivar best suits the market niche of small farmers.
\end{abstract}

KEYWORDS: Phaseolus vulgaris. Productivity. Nutritional efficiency. Technological level.

\section{INTRODUCTION}

Brazil ranks high among the largest bean producers and consumers (Phaseolus vulgaris L.) in the world. Beans are rich in vitamins and proteins and form the staple food of Brazil's population (TSUTSUMI; BULEGON; PIANO, 2015). Beans produced in Brazil amount in total to 572 thousand tons, with the State of Goiás registering the highest average productivity at $2,100 \mathrm{~kg} \mathrm{ha}^{-1}$ for the $2019 / 20$ crop, exceeding the national average of $571 \mathrm{~kg} \mathrm{ha}^{-1}$ (CONAB, 2020). However, average bean productivity continues to be considered poor in relation to the yield potential of the cultivars available in the market, which surpasses $3,000 \mathrm{~kg}$ $\mathrm{ha}^{-1}$ (FARINELLI; LEMOS, 2010).

Cultivar management is not suitable under some specific conditions in terms of restricted availability of nutrients in the soils and inefficient mineral nutrition, which are the determining factors for low grain yields (OLIVEIRA et al., 2012; NASCENTE et al., 2014). The poor quality of organic matter, high-degree of acidity, and aluminum toxicity of the Cerrado soils render them low in fertility but with a high P-adsorbing capacity.
The nutrients crucial for bean cultivation include I - Nitrogen $(\mathrm{N})$, a chlorophyll constituent responsible for photoassimilate production and dry mass accumulation (ARF et al., 2011); II Phosphorus (P) is significant as an energy transfer determinant, as well as essential for plant development and seed quality (ZUCARELI et al., 2011); III - Potassium (K), is essential for translocation and ionic balance, controlling grain filling (SOUSA et al., 2013). As beans have high nutritional needs, fertilizers are extensively applied in an attempt to ensure high grain yield. This has resulted in economic losses and environmental backlashes (SANT'ANA et al., 2011). The nutrients left unabsorbed by the plants get leached and finally end up in water bodies resulting in eutrophication and depletion of natural deposits, which in turn, are linked to the escalation of production costs (CONANT et al., 2013).

Therefore, genetic improvement programs, in their attempt to cope with these impediments, select superior genotypes providing high yields under low fertilizer doses (MELO et al., 2018). One such method being implemented is the assessment of agronomic efficiency. Some of the common bean cultivars identified by several authors (SOUSA et 
al., 2012; SANT'ANA; SANTOS; SILVEIRA, 2011; FARINELLI; LEMOS, 2010; OLIVEIRA et al., 2012; GALVÃO et al., 2013), reveal greater efficiency and responsiveness to the soil nutrients. Therefore, such superior cultivars, which can optimize the use of the soil nutrients, need to be selected. This type of selection must be a priority as the present demands of the agricultural market require high yields to be maintained at low production costs. This process must also be continuous because new, agronomically superior cultivars are being produced every year.

Hence, this study aimed to identify the common bean cultivars that have high efficiency and responsiveness to $\mathrm{N}, \mathrm{P}$ and $\mathrm{K}$, and even better, if possible, simultaneously. It also aims at directing the cultivar producers to implement suitable levels of technology.

\section{MATERIAL AND METHODS}

The experiments were performed at Universidade de Estadual de Goiás (UEG) during the 2014/15 harvest when the sowing was done. Three field experiments were conducted, one for each nutrient ( $\mathrm{N}, \mathrm{P}$, and $\mathrm{K})$, when all the nutrients were applied at the recommended doses, barring the nutrient being investigated. The randomized block design was adopted for the experiments in a factorial scheme $(11 \times 4)$ with nine cultivars and two pre-commercial bean lines supplied by EMBRAPA Rice and Bean in four nutrient doses with three replicates.

The cultivars assessed included BRS Agreste and BRS Marfim. Both grains are the mulatto type: BRS Ametista, BRS Cometa, BRS Estilo, BRS Notável, Pérola, BRS Pontal, and BRS Sublime, all grains of the Carioca type and the precommercial lines using the grains of the Carioca type CNFC 10729 and CNFC 10762. The nutrients, nitrogen, and phosphorus, were supplied in the following doses $\left(0,53,106,160 \mathrm{~kg} \mathrm{ha}^{-1}\right.$ of $\mathrm{N}$ and $\left.\mathrm{P}_{2} \mathrm{O}_{5}\right)$ and potassium $\left(0,30,60,90 \mathrm{~kg} \mathrm{ha}^{-1}\right.$ of $\left.\mathrm{K}_{2} \mathrm{O}\right)$. The doses applied for the beans included low availability, partial availability, recommended and surplus quantities, depending on the recommendations of Barbosa et al. (2012), with urea $\left(\begin{array}{ll}45 \% & \mathrm{~N}\end{array}\right)$, phosphate triple $\left(\begin{array}{lll}41 \% & \mathrm{P}_{2} \mathrm{O}_{5}\end{array}\right)$, and potassium chloride $\left(60 \% \mathrm{~K}_{2} \mathrm{O}\right)$ as the sources used. Each plot included four rows $3 \mathrm{~m}$ in length, with 45 $\mathrm{cm}$ spacing, and with only the two central rows assessed to give a floor area of $2.7 \mathrm{~m}^{2}$.

The experimental area was characterized by Dystrophic Red Latosol soil type of a texture that included clay, silt, and sand at 300, 80, 620, respectively. The soil, prior to fertilization and acidity correction, had the following chemical characteristics: $\mathrm{pH}-5.1$; organic material $20.6 \mathrm{~g} \mathrm{dm}^{-}$ ${ }^{3}$; P $1.2 \mathrm{mg} \mathrm{dm}^{-3}$; $\mathrm{H}+\mathrm{Al} 2.3 \mathrm{cmol}_{\mathrm{c}} \mathrm{dm}^{-3}$; K $0.1 \mathrm{mmol}_{\mathrm{c}}$ $\mathrm{dm}^{-3}$; Ca $1.6 \mathrm{cmol}_{\mathrm{c}} \mathrm{dm}^{-3} ; \mathrm{Mg} 0.7 \mathrm{cmol}_{\mathrm{c}} \mathrm{dm}^{-3} ; \mathrm{SB}$ $49.9 \mathrm{cmol}_{\mathrm{c}} \mathrm{dm}^{-3}$; CTC $4.7 \mathrm{cmol}_{\mathrm{c}} \mathrm{dm}^{-3}$; V\% 15.5.

Twenty days before planting, $2.6 \mathrm{t} \mathrm{ha}^{-1}$ of limestone was added, and the soil was conventionally prepared by one plowing and two harrowing procedures. Planting was manually done, and 15 seeds were sown per meter. After thinning, only 10 plants per meter remained. Next, urea cover fertilization $(45 \% \mathrm{~N})$ was applied 20 days after emergence. Half the amount was first applied at the base and the other half was used as coverage for all the treatments except for the nitrogen-free application. Weed control was manually performed every 15 days until the $\mathrm{V}_{4}$ stage was reached. Pest and disease management was conducted during the vegetative and reproductive stages based on crop needs.

In all three experiments, the variable grain yield was analyzed by obtaining the total weight of the grains of all the plots and transforming them to $\mathrm{kg} \mathrm{ha}^{-1}$ with humidity corrected to $13 \%$. To interpret the data, the analysis of variance was performed using the SISVAR computer program (FERREIRA, 2011).

To classify the cultivars in terms of agronomic efficiency to $\mathrm{N}, \mathrm{P}$, and $\mathrm{K}$, the method of Rodrigues et al. (2014) was followed in which the cultivars were categorized based on the efficiency and responsiveness for each nutrient. This was calculated via the productivities in response to the doses applied to the soil according to the equation given:

$$
\text { EFAGRO }_{\left(N_{0} P e K\right)}=\frac{\left(G Y_{a}-G Y_{b}\right)}{\left(N D_{a}\right)}
$$

Where,

EFAGRO $(\mathrm{N}, \mathrm{P}$, or $\mathrm{K})=$ agronomic efficiency, meaning the response or responsiveness index for each nutrient $\left(\mathrm{kg} \mathrm{kg}^{-1}\right)$;

$\mathrm{GY}_{\mathrm{a}}=$ grain yield with fertilizer application, equivalent to adequate and high availability;

$\mathrm{GY}_{\mathrm{b}}=$ grain yield without fertilizers, equivalent to low and partial nutrient availability;

$\mathrm{ND}_{\mathrm{a}}=$ differences in the nutrient doses applied to the soil with sufficient (or high) and low (or partial) nutrient availability.

After interpreting the data, they were included in a Cartesian plane, shown as graphs, where the $\mathrm{x}$ axis (of the abscissae) enabled the 
cultivar efficiency to be identified, while the y-axis (of ordinates), indicated the responsive effect or agronomic efficiency. The cultivars were thus classified under four categories as efficient and responsive (ER), inefficient and responsive (IR), inefficient and non-responsive (INR), and efficient and non-responsive (ENR).

\section{RESULTS AND DISCUSSION}

The significant effects were noted for all the sources of variation $(p \geq 0,05)$, as well as for all three nutrients, revealing the presence of variability between the cultivars and lineages (Table 1). The coefficients of variation hovered between $15 \%$ and $16 \%$, which were suitable values for field experiments and within the values anticipated for nutritional efficiency (Table 1).

The ideotype desired for genetic enhancement needed to possess greater nutritional efficiency with superior performance even under conditions of low nutrient availability and ability to raise its output correspondingly as the available nutrient for the plant increased. Thus, the ER (efficient and responsive) classification types best indicated the type of plant and lineage to be selected.

Table 1. Analyses of variance for the grain yield of 11 cultivars grown under different availability of nitrogen, phosphorus $\left(0,53,106,160 \mathrm{~kg} \mathrm{ha}^{-1} \mathrm{~N}\right.$ and $\left.\mathrm{P}_{2} \mathrm{O}_{5}\right)$, and potassium $\left(0,47,94,140 \mathrm{~kg} \mathrm{ha}^{-1} \mathrm{~K}_{2} \mathrm{O}\right)$.

\begin{tabular}{lllll}
\hline SV & DF & N & $\mathrm{P}$ & $\mathrm{K}$ \\
\hline Cultivars (C) & 10 & $946047^{* *}$ & $1070475^{* *}$ & $753354^{* *}$ \\
Doses (D) & 3 & $1738031^{* *}$ & $3116095^{* *}$ & $963430^{* *}$ \\
C x D & 30 & $113397^{*}$ & $91053^{*}$ & $146662^{* *}$ \\
Blocks & 2 & 5025698 & 4599216 & 3810081 \\
Error & 86 & 50787 & 38241 & 51477 \\
\hline CV $(\%)$ & 15.02 & 16.14 & 15.87 \\
\hline
\end{tabular}

Ipameri, GO, 2020.

$\mathrm{SV}=$ source of variation; $\mathrm{DF}-$ degree of freedom; ${ }^{* *}$ and ${ }^{*}-$ significant at 1 and $5 \%$ probability, by the $\mathrm{F}$ test; CV\% - coefficient of variation.

\section{Nitrogen}

The BRS Estilo (C4) and Pérola (C7) cultivars, according to the ER classification, were unaffected by the $\mathrm{N}$ availability (Figures $1 \mathrm{~A}, 1 \mathrm{~B}, 1 \mathrm{C}$ and 1D), unlike the BRS Notável (C6) under low availability (Figures $1 \mathrm{~A}$ and $1 \mathrm{C}$ ), indicated higher ability to adapt to different levels of $\mathrm{N}$ availability in the soil. According to Sant'Ana et al. (2011), the agronomic efficiency revealed a quadratic decreasing pattern when $30 \mathrm{~kg} \mathrm{ha}^{-1}$ of $\mathrm{N}$ was applied as the initial availability and gradually increased up to $240 \mathrm{~kg} \mathrm{ha}^{-1}$. It is noteworthy that the agronomic and physiological efficiency were observed to intersect approximately at the $120 \mathrm{~kg} \mathrm{ha}^{-1}$ dose of $\mathrm{N}$, regarded as the fitting dose for the BRS Horizonte, similar to the pattern revealed by the cultivar BRS Agreste. However, when this value is surpassed (Figures 1B and 1D), no further responsive effect is noted.

Farinelli and Lemos (2010) reported high values in the bean cultivars for agronomic efficiency with Pérola evaluated in response to the 40 and 120 $\mathrm{kg} \mathrm{ha}^{-1}$ doses and later by a decrease in response to the $160 \mathrm{~kg} \mathrm{ha}^{-1}$ dose. Under the conventional cultivation system, they also calculated the efficiencies dose-wise. This behavior is clearly evident from Figure 1A when compared with Figures $1 \mathrm{C}$ and $1 \mathrm{~B}$ to $1 \mathrm{D}$ for this same cultivar. There is also a drop in the EFAGRO when the dose applied increased from 106 to $160 \mathrm{~kg} \mathrm{ha}^{-1}$ of $\mathrm{N}$, confirming that performance declines when $\mathrm{N}$ dose is raised and its responsive effect also decreases.

To ensure genetic improvement focusing on nutritional efficiency, a wide variability is required. As heritability decreases with availability, the genotype-environment interactions are very high. However, care must be taken in genotype selection, which in most instances can be determined by the technological level recommended for implementation. Thus, cultivars with high $\mathrm{N}$ efficiency are suitable for crops requiring low levels of technology (low-input agriculture) with minimum use of $\mathrm{N}$ fertilizers, thus cutting production costs and reducing environmental damage (CANCELLIER et al., 2011). For example, the cultivar BRS Cometa (C3) is appropriate for 
plantations experiencing conditions of very low availability (Figures $1 \mathrm{~A}$ and $1 \mathrm{C}$ ), whereas the BRS Notável (C6) is suitable for low fertilizer applications (Figures $1 \mathrm{~B}$ and 1D). This means genotypes with high nodulation capacity are available, which encourage higher efficiency in the biological nitrogen fixation cycle, facilitating higher and more significant productivities under conditions of $\mathrm{N}$ availability in the soil, as reported by Salgado et al. (2012).

The cultivar BRS Notable (C6) reveals high productivity of about $1,500 \mathrm{~kg} \mathrm{ha}^{-1}$, and under conditions of low $\mathrm{N}$ availability (Figures 1A and $1 \mathrm{C})$, was the highest among six cultivars. However, when a dose of merely $53 \mathrm{~kg}$ of $\mathrm{N}$ is applied, this cultivar exceeds all 11 genotypes (Figures $1 \mathrm{~B}$ and 1D), recording an approximately $1,100 \mathrm{~kg}$ increase. This indicates the importance of identifying cultivars possessing high efficiencies for each environment. Also, most likely linked to its high productive ability, this cultivar exhibits enormous stability in different environments, as well as resistance to several significant diseases common among bean plants (PEREIRA et al., 2012).

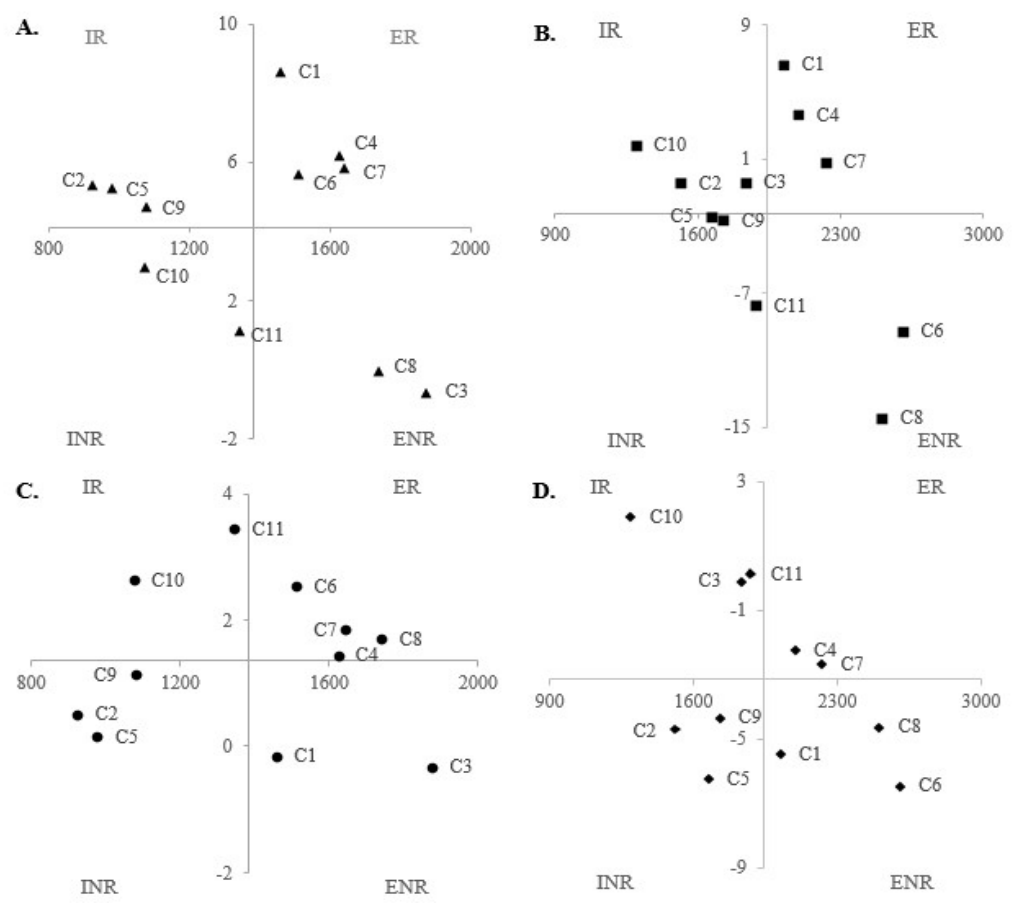

Figure 1. Efficiency $\left(\mathrm{kg} \mathrm{ha}^{-1}\right)$ and responsiveness $\left(\mathrm{kg} \mathrm{kg}^{-1}\right)$ of the bean cultivars, BRS Agreste (C1), BRS Ametista (C2), BRS Cometa (C3), BRS Estilo (C4), BRS Marfim (C5), BRS Notável (C6), Peróla (C7), BRS Pontal (C8), BRS Sublime (C9), CNFC 10729 (C10), and CNFC10762 (C11), based on their responses to different nitrogen availabilities, were represented as A (low and adequate dose), B (partial and adequate dose), C (low and nutritional excess), and D (partial and nutritional excess). Ipameri, GO, 2020.

According to the agronomic efficiency or response index of Sousa et al. (2012) for the bean cultivar assessment, the cultivar BRS Marfim showed IR performance similar to Figure 1A. However, at higher doses, this cultivar exhibits low performance for responsiveness as well as low efficiency when compared with the other cultivars evaluated. It is therefore categorized as INR for the other three conditions, concurring with the findings of Salgado et al. (2012). This clearly shows that the EFAGRO assessment under only one single condition can affect the researcher's conclusion and lower the likelihood of gaining an advantage in selecting efficient and N-responsive cultivars.

It is important that the form of the $\mathrm{N}$ application must be taken into account when raising the efficiency and responsiveness of the bean plant. In fact, Nascente et al. (2012) discovered that when the $30 \mathrm{~kg}$ dose was initially applied and again $30 \mathrm{~kg}$ $\mathrm{ha}^{-1}$ of $\mathrm{N}$ applied after 12 days of emergence, the Pérola cultivar revealed an enhanced ability to utilize it. The Pérola was noted to be classified as ER for the different conditions using a similar dose (and subdivided also when $53 \mathrm{~kg} \mathrm{ha}^{-1}$ is used). However, if the dose is applied only at the time of 
planting or only in coverage, there is a tendency for productivity to decrease, as the author of this study has reported.

\section{Phosphorus}

Rotili et al. (2010), Wang, Shen and Liao (2010) and Lynch (2011) reported that the plant efficiency in response to the phosphatic application is controlled by the capability of the genetic material to develop different adaptive mechanisms to overcome the stress, such as absorption, translocation, and internal use, presence of root hair and lateral root growth, presence of mycorrhizae and increase in root number among other features for grain formation apart from internally utilizing nutrients more efficiently and translocating them more easily in the plant. The cultivars BRS Ametista (C2) and CNFC 10729 (C10) were unable to acquire the $\mathrm{P}$ under conditions of low availability and were classified as INR, which possibly indicates low amounts of these mechanisms (Figures $2 \mathrm{~A}$ to 2D).

The cultivar BRS Cometa (C3) more efficiently acquires the $\mathrm{P}$ even in environments with lower availability. This is evident because in response to only $47 \mathrm{~kg} \mathrm{ha}^{-1}$ of $\mathrm{P}_{2} \mathrm{O}_{5}$ applied, its productivity rose just by $212 \mathrm{~kg}$ on average, whereas the BRS Pontal (C8) raised its productivity by $1,200 \mathrm{~kg}$, demonstrating that the cultivars possess different nutrient acquisition or utilization mechanisms (Figures 2A, 2B, 2C and 2D).
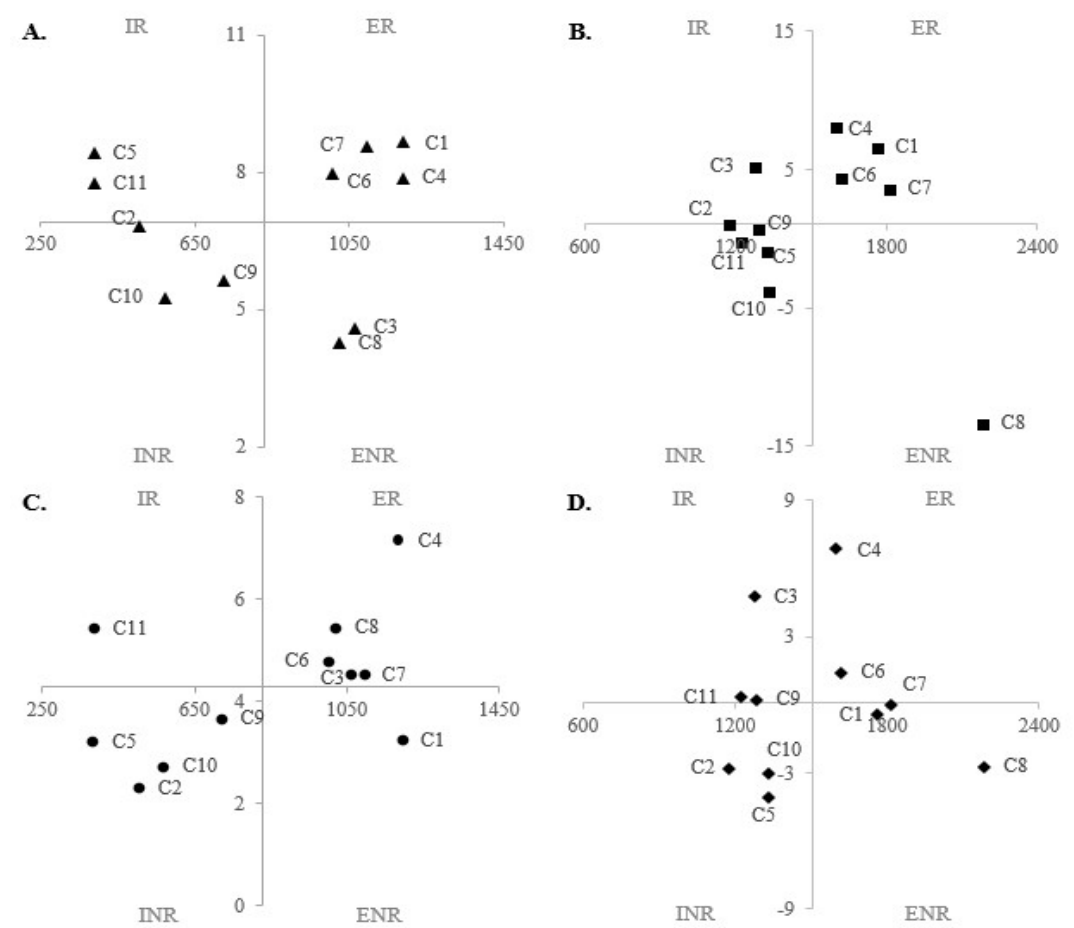

Figure 2. Efficiency $\left(\mathrm{kg} \mathrm{ha}^{-1}\right)$ and responsiveness $\left(\mathrm{kg} \mathrm{kg}^{-1}\right)$ of the bean cultivars, BRS Agreste (C1), BRS Ametista (C2), BRS Cometa (C3), BRS Estilo (C4), BRS Marfim (C5), BRS Notável (C6), Pérola (C7), BRS Pontal (C8), BRS Sublime (C9), CNFC 10729 (C10), and CNFC10762 (C11), based on their responses to different phosphorus availabilities, were represented as $\mathrm{A}$ (low and adequate dose), B (partial and adequate dose), C (low and nutritional excess), and D (partial and nutritional excess).

Ipameri, GO, 2020.

Oliveira et al., (2012) also presented a classification of the bean genotypes of the Cerrado soils in terms of efficiency and responsiveness to phosphorus. They reported productivity and average responsiveness of $611 \mathrm{~kg} \mathrm{ha}^{-1}$ and $7.7 \mathrm{~kg} \mathrm{~kg}^{-1}$, respectively, in response to the application of 20 and $120 \mathrm{~kg} \mathrm{ha}^{-1}$ of $\mathrm{P}_{2} \mathrm{O}_{5}$ as super simple ammoniacal fertilizer and also indicated the cultivars suitable for each niche market. Figures $2 \mathrm{~A}$ and $2 \mathrm{C}$ revealed a value lesser than the one noted under low availability, which was $827 \mathrm{~kg}$ and similar for the responsiveness of $7.0 \mathrm{~kg} \mathrm{~kg}^{-1}$.

The cultivar Pérola evaluated by Nascente et al. (2014) from the perspective of the utilization efficiency of $\mathrm{P}$ via foliar and soil applications, identified that this combined application through 
soil and leaf was the most effective. Based on the productivity results of this work with the fertilizer application via the soil, the cultivar presented an agronomic efficiency around 2.6 and $1.5 \mathrm{~kg} \mathrm{~kg}^{-1}$, with the values obtained in doses 0 and $120 \mathrm{~kg}$ and 40 and $120 \mathrm{~kg}$ of $\mathrm{P}_{2} \mathrm{O}_{5}$ also observed in Figures $2 \mathrm{~A}$ and $2 \mathrm{~B}$; however, with superior performance with values of 8.6 and $3.8 \mathrm{~kg} \mathrm{~kg}^{-1}$, respectively.

According to Zucareli et al. (2011), the early Carioca cultivar recorded high dry matter mass and foliar area linearly in response to phosphorus doses up to $150 \mathrm{~kg} \mathrm{ha}^{-1}$ of $\mathrm{P}_{2} \mathrm{O}_{5}$. Viana et al. (2011), however, studying the same cultivar, recorded a maximum of $201 \mathrm{~kg} \mathrm{ha}^{-1}$ of $\mathrm{P}_{2} \mathrm{O}_{5}$. The stabilization of efficiency can be identified between 100 and 200 $\mathrm{kg}$ doses. Additionally, between the 150 and $200 \mathrm{~kg}$ doses, the increase is low at approximately $61 \mathrm{~kg}$, with the agronomic efficiency gradually reducing, as evident from Figures $2 \mathrm{~A}$ and $2 \mathrm{C}$ and between $2 \mathrm{~B}$ and $2 \mathrm{D}$.

Lazali et al. (2014) evaluated the application of $\mathrm{P}$ in contrasting strains of Phaseolus vulgaris $\mathrm{L}$. and its role in $\mathrm{N}$ fixation. Additionally, genotypes that possessed high-efficiency use in $\mathrm{P}$ could be identified through $\mathrm{N}_{2}$ fixation. They could also confirm the similarity between the classifications for $\mathrm{N}$ and $\mathrm{P}$. In fact, on average, $82 \%$ of similarity was observed between the classifications with few modifications, as noted in BRS Ametista (C2), in Figures $1 \mathrm{~A}$ and $2 \mathrm{~A}$. This ascertained the presence of a closer relationship between the use of these nutrients, as well as agronomic efficiency in beans. Bargaz et al. (2016) reported for common bean plants the possibility of raising the tolerance levels to saline soils via the precise supply of $\mathrm{P}$, thus reiterating that efficiency and responsiveness may also be linked to salinity tolerance.

\section{Potassium}

The lowest number of ER cultivars observed was for K. Only the BRS Agreste (C1) and BRS Estilo (C4) cultivars expressed this behavior under the different conditions as evident from Figures 3A, $3 \mathrm{~B}, 3 \mathrm{C}$, and 3D. Low efficiency was also noted in the CNFC 107259 and CNFC 10762 under stress conditions (Figures 3A and 3C). However, they did register a good degree of productivity increase with the dose of only $30 \mathrm{~kg} \mathrm{ha}^{-1}$ of $\mathrm{K}_{2} \mathrm{O}$ (Figures $3 \mathrm{C}$ and $3 \mathrm{D})$. The higher agronomic efficiency to $\mathrm{K}$ may permit increased salinity tolerance, as recorded by Dawood et al., (2014). They reported that the common bean plants showed attenuated effects of salinity but an increase in the photosynthetic pigments and antioxidant enzyme activity when $\mathrm{K}$ was applied to the soil.
In their work on beans, Leal and Prado (2008) determined the nutritional disorders caused by the deficits of the macronutrients boron (B) and zinc $(\mathrm{Zn})$ and singled out $\mathrm{K}$ as the nutrient that most intensely influenced the vegetative growth variables and dry matter, closely followed by $\mathrm{P}$ and $\mathrm{N}$. Although it plays such a vital role, $\mathrm{K}$ is the one element with the least number of studies, although the literature contains a few that investigate its efficiency and responsiveness in Phaseolus vulgaris L.

It was Galvão et al. (2013) who discovered that productivity would drop when $\mathrm{K}$ was present in excess in the soil. Excess $\mathrm{K}$ would exert an antagonistic effect on the other cations, like $\mathrm{Ca}, \mathrm{Mg}$, $\mathrm{N}$, and $\mathrm{P}$, exhibiting a negative interference in the productivity constituents of the plants. Thus, the cultivars showing higher responsiveness will increase their yield in response to the $\mathrm{K}$ dose applied to the soil without requiring high doses. This poses less risk to the toxicity producer as noted in the cultivar Pérola (C7) from Figures 3A to 3D.

The greater divergence among the cultivars observed in the $\mathrm{K}$ behavior than in the $\mathrm{N}$ and $\mathrm{P}$ is noteworthy. The BRS Notável (C6) cultivar clearly exhibits high efficiency under conditions of greater stresses (Figures 3A and 3C), which decreases when $47 \mathrm{~kg} \mathrm{ha}^{-1} \mathrm{~K}_{2} \mathrm{O}$ is applied in partial availability (Figures 3B and 3D), inducing strong changes in its performance. The BRS Pontal (C8) cultivar that exhibited good efficiency under low availability (Figures 3A to 3D) may be, according to Rengel and Damon (2008), due to the differences linked to the more effective absorption mechanisms, larger contact area, efficient $\mathrm{K}$ translocation between the plant organs, and heightened substitution capacity in $\mathrm{Na}^{+}$by $\mathrm{K}^{+}$, among others, thus implying that this cultivar holds promise for further investigation regarding the efficiency of this nutrient in these plants.

White (2013) categorizes the different mechanisms by which the efficient plant would acquire the nutrient from deficient soil through mechanisms like the higher release of organic compounds and greater discharge of $\mathrm{K}$, intense $\mathrm{K}$ uptake capacity of the roots and, the vigor of the roots, in particular, that could be extended in volume, length, and density. However, in response to the $\mathrm{K}$ applied, in this case to the responsive effect, the mechanism involved would be the effective redistribution $\mathrm{K}$ within the plant, low $\mathrm{K}$ concentration in the tissue, and $\mathrm{K}$ concentrations maintained in active cellular compartments, among others, as well as the harvesting or responsiveness index. 
From Figures 3A and 3B, the Pérola cultivar (C7) would possibly be the one to agglomerate the most number of such mechanisms when $94 \mathrm{~kg} \mathrm{ha}^{-1}$ of $\mathrm{K}_{2} \mathrm{O}$ was applied, showing values of 5.3 and 8.6 $\mathrm{kg} \mathrm{kg}^{-1}$, respectively. The BRS Estilo (C4) and BRS Marfim (C5) cultivars, revealing mean values of 6.0 and $5.2 \mathrm{~kg} \mathrm{~kg}^{-1}$ respectively, were identified as the most responsive to the doses applied (Figures 3C and 3D), thus indicating the diversity between the mechanisms within the cultivars.

The cultivar BRS Agreste (C1), BRS Estilo (C4), BRS Notável, and Pérola (C7) have the highest number of ER classifications identified for low and high technological levels, as shown in Figures 1, 2 and 3. On the contrary, the cultivars BRS Ametista (C2) and BRS Sublime (C9) with INR classification, exhibited poor ability to acquire or utilize the nutrients for grain formation (efficiency agronomic). This group of cultivars in the present study is noteworthy as they show divergence and can express changes in their classification with other cultivars being inserted or even with the doses altered.

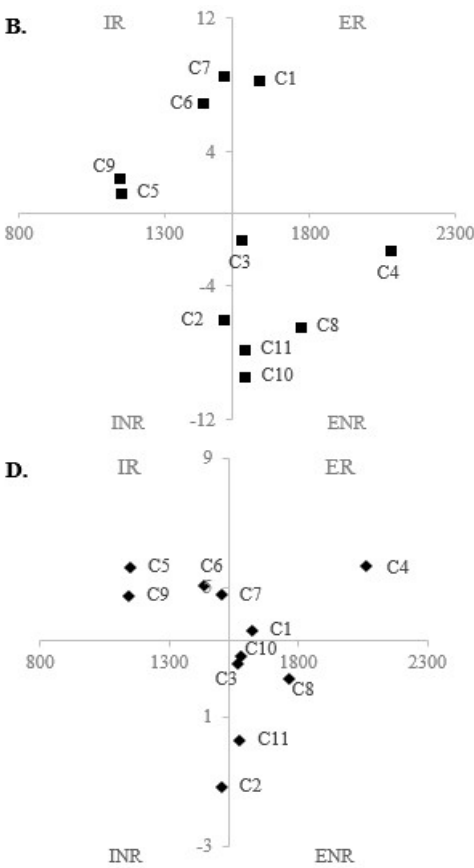

Figure 3. Efficiency $\left(\mathrm{kg} \mathrm{Kg}^{-1}\right)$ and responsiveness $\left(\mathrm{kg} \mathrm{kg}^{-1}\right)$ of the bean cultivars, BRS Agreste (C1), BRS Ametista (C2), BRS Cometa (C3), BRS Estilo (C4), BRS Marfim (C5), BRS Notável (C6), BRS Pontal (C8), BRS Sublime (C9), CNFC 10729 (C10), and CNFC10762 (C11), based on their responses to different potassium availabilities, were represented as A (low and adequate dose), B (partial and adequate dose), C (low and nutritional excess), and D (partial and nutritional excess). Ipameri, GO, 2020.

According to Melo et al. (2010), the BRS Estilo cultivar showed adaptations to various geographic areas of Brazil and displayed a higher productive potential than the control, which is likely due to its greater ability to more efficiently utilize the nutrients, as well as to its higher responsive effect (Figures 1, 2, and 3). Out of the 11 cultivars assessed, the BRS Estilo (C4) was the only one to show values of efficiency and responsiveness ranking among the three highest values. The BRS Ametista (C2) had the lowest values among the cultivars.

The cultivar BRS Pontal (C8) for N, P, and $\mathrm{K}$ when subjected to different availability revealed high efficiency or above-average performance, implying that it is more of a rustic cultivar that will suit the niche market of small producers (Figures 1, 2 , and 3 ). This finding concurred with the results of Melo et al. (2018) who inferred that the same cultivar is better suited for family agriculture and more restricted technology. Simultaneous efficiencies can also be investigated to generate promising genotypes. However, cultivar selection should be prioritized to suit the region in which a particular nutrient is most lacking and with the possibility that the cultivar will increase its productivity gain with the lower fertilizer application as well as be amenable to the technological level to be implemented. 


\section{CONCLUSIONS}

Genetic variability is noted among the bean cultivars for efficiency and responsiveness (agronomic efficiency) to nitrogen, phosphorus, and potassium.

The cultivars BRS Agreste, BRS Estilo, BRS Notável, and Pérola reveal the highest number of efficient and responsive grades for nitrogen, phosphorus, and potassium and are indicated for low and high technological levels.

On the contrary, the BRS Ametista and BRS Sublime cultivars classified as inefficient and nonresponsive show a poor capacity to acquire or utilize the nutrients for grain formation. For all the three nutrients, the BRS Pontal cultivar shows high or above-average efficiency under different availability nutritional, demonstrating that it is more of a rustic cultivar and therefore suitable for the niche market of small producers.

\section{ACKNOWLODGEMENTS}

The authors express their gratitude to the FAPEG (Fundação de Amparo à Pesquisa do Estado de Goiás), Embrapa Rice and Bean and the Universidade Estadual de Goiás for granting the PROBIP.

RESUMO: O objetivo do trabalho foi identificar e classificar novas cultivares de feijoeiro quanto a eficiência e responsividade ao nitrogênio, fósforo e potássio, de forma individual e simultânea, além de indicar as cultivares para cada nicho de mercado, de acordo com essa classificação. Foram realizados três experimentos em campo, separados por nutriente, com delineamento de blocos casualizados, em esquema fatorial (11 x 4), sendo 11 cultivares em quatro doses, com três repetições. A variável analisada foi a produtividade de grãos e as médias utilizadas para a classificação, separando-se por nutriente, em quatro disponibilidades, sendo baixo, parcial, dose adequada e excesso nutricional. Existe variabilidade genética para eficiência e responsividade (eficiência agronômica) entre os cultivares de feijão, para nitrogênio, fósforo e potássio. As cultivares BRS Agreste, BRS Estilo, BRS Notável e a Pérola são as que possuem maior número de classificações eficientes e responsivas para nitrogênio, fósforo e potássio, sendo indicadas para baixo e alto nível tecnológico. Em sentido oposto, as cultivares BRS Ametista e a BRS Sublime com classificação ineficiente e não-responsiva, com baixa capacidade de adquirir ou utilizar os nutrientes para a formação de grãos. A cultivar BRS Pontal para nitrogênio, fósforo e potássio, apresenta uma eficiência alta ou acima da média sob os diferentes estresses, o que indica que é uma cultivar mais rústica e que atende o nicho de mercado de pequenos produtores.

PALAVRAS-CHAVE: Phaseolus vulgaris L. Produtividade. Eficiência nutricional. Nível tecnológico.

\section{REFERENCES}

ARF, M. V.; BUZETTI, S.; ARF, O.; KAPPES, C.; FERREIRA, J. P.; GITTI, D. C.; YAMAMOTO, C. J. T. Fontes e épocas de aplicação de nitrogênio em feijoeiro de inverno sob sistema plantio direto. Pesquisa Agropecuária Tropical, Goiânia, v. 41, n. 3, p. 430-438, 2011. https://doi.org/10.5216/pat.v41i3.9706

BARBOSA, F. R.; GONZAGA, A. C. O. Informações técnicas para o cultivo do feijoeiro-comum na Região Central-Brasileira: 2012-2014. 1 ed. Santo Antônio de Goiás: Embrapa Arroz e Feijão, 2014. 247p. [cited 2017-10-05]. Available from Internet: http://ainfo.cnptia.embrapa.br/digital/bitstream/item/61388/1/seriedocumentos-272.pdf

BARGAZ, A.; NASSAR, R. M. A.; RADY, M. M.; GABALLAH, M. S.; THOMPSON, S. M.; BRESTIC, M.; SCHIDHALTER, U.; ABDELHAMID, M. T. Improved Salinity Tolerance by Phosphorus Fertilizer in Two Phaseolus vulgaris Recombinant Inbred Lines Contrasting in Their P-Efficiency. Journal of Agronomy and Crop Science, v. 202, n. 6, p. 497-507, 2016. https://doi.org/10.1111/jac.12181

CANCELLIER, E. L.; BARROS, H. B.; KISCHEL, E.; GONZAGA, L. A.; BRANDÃO, D. R.; FIDELIS, R. R. Eficiência agronômica no uso de nitrogênio mineral por cultivares de arroz de terras altas. Revista

Brasileira de Ciências Agrárias, Pernambuco, v. 6, n. 4, p. 650-656, 2011.

https://doi.org/10.5039/agraria.v6i4a1420 
CONAB - Companhia Nacional de Abastecimento. Acompanhamento da safra brasileira de grãos, safra 2019/20, 6 Levantamento, março/2020. [cited 2020-04-10]. Available from Internet:

https:/www.conab.gov.br/info-agro/safras/graos.

CONANT, R. T.; BERDANIER. A. B.; GRACE, P. R. Patterns and trends in nitrogen use and nitrogen recovery efficiency in world agriculture. Global Biogeochemical Cycles, v. 27, n. 2, p. 558-566, 2013. https://doi.org/10.1002/gbc.20053

DAWOOD, M. G.; ABDELHAMID, M. T.; SCHMIDHALTER, U. Potassium fertiliser enhances the salttolerance of common bean (Phaseolus vulgaris L.). The Journal of Horticultural Science and

Biotechnology, v. 89, n. 2, p. 185-192. 2014. https://doi.org/10.1080/14620316.2014.11513067

FARINELLI, R.; LEMOS, L. B. Produtividade, eficiência agronômica, características nutricionais e tecnológicas do feijão adubado com nitrogênio em plantio direto e convencional. Bragantia, Campinas, v. 69, n. 1, p. 165-172, 2010. http://dx.doi.org/10.1590/S0006-87052010000100021

FERREIRA, D. F. Sisvar: A computer statistical analysis sytem. Ciência e agrotecnologia, Lavras, v. 35, n. 6, p. 1039-1042, 2011. http://dx.doi.org/10.1590/S1413-70542011000600001

GALVÃO, J. R.; FERNANDES, A. R.; MELO, N. C.; SILVA, V. F. A.; ALBUQUERQUE, M. P. F. Sistemas de manejo e efeito residual do potássio na produtividade e nutrição do feijão-caupi. Revista Caatinga, Mossoró, v. 26, n. 2, p. 41-49, 2013.

LAZALI, M.; BARGAZ, A.; CARLSSON, G.; OUNANE, S. M.; DREVON, J. J. Discrimination against ${ }^{15} \mathrm{~N}$ among recombinant inbred lines of Phaseolus vulgaris L. contrasting in phosphorus use efficiency for nitrogen fixation. Journal of Plant Physiology, v. 171, n. 3-4, p. 199-204, 2014.

https://doi.org/10.1016/j.jplph.2013.07.009

LEAL, R. M.; PRADO, R. M. Desordens nutricionais no feijoeiro por deficiência de macronutrientes, boro e zinco. Revista Brasileira de Ciências Agrárias, Pernambuco, v. 3, n. 4, p. 301-306, 2008.

https://doi.org/10.5039/agraria.v3i4a322

LYNCH, J. P. Root phenes for enhanced soil exploration and phosphorus acquisition: tools for future crops. Plant physiology, v. 156, n. 3, p. 1041-1049, 2011. https://doi.org/10.1104/pp.111.175414

MELO, L. C.; DEL PELOSO, M. J.; PEREIRA, H. S.; FARIA, L. C.; COSTA, J. G. C.; DÍAZ, J. L. C.; RAVA, C. A.; WENDLAND, A.; ABREU, Â. F. B. BRS Estilo - Common bean cultivar with Carioca grain, upright growth and high yield potential. Crop Breeding and Applied Biotechnology, Viçosa, v. 10, n. 4, p. 377-379, 2010. http://dx.doi.org/10.1590/S1984-70332010000400015

MELO, P. G. S.; ALVARES, R. C.; PEREIRA, H. S.; BRAZ, A. J. B. P.; FARIA, L. C.; MELO, L. C. Adaptability and stability of common bean genotypes in family farming systems. Pesquisa Agropecuária Brasileira, Brasília, v. 53, n. 2, p. 189-196, 2018. http://dx.doi.org/10.1590/s0100-204x2018000200007

NASCENTE, A. S.; KLUTHCOUSKI. J.; CRUSCIOL, C. A. C.; COBUCCI, T.; OLIVEIRA, T. Adubação de cultivares de feijoeiro comum em várzeas tropicais. Pesquisa Agropecuária Tropical, Goiânia, v. 42, n. 4, p. 407-415, 2012. https://doi.org/10.1590/S1983-40632012000400003

NASCENTE, A. S.; COBUCCI, T.; SOUSA, D. M. G.; LIMA, D. P. Adubação fosfatada no sulco e foliar afetando a produtividade de grãos do feijoeiro comum. Semina: Ciências Agrárias, Londrina, v. 35, n. 3, p. 1231-1240, 2014. http://dx.doi.org/10.5433/1679-0359.2014v35n3p1231

OLIVEIRA, T. C.; SILVA, J.; SALGADO, F. H. M.; SOUSA, S. A.; FIDELIS, R. R. Eficiência e resposta à aplicação de fósforo em feijão comum em solos de cerrado. Revista Verde de Agroecologia e

Desenvolvimento Sustentável, Mossoró, v. 7, n. 1, p. 16-24, 2012. 
PEREIRA, H. S.; WENDLAND, A.; MELO, L. C.; PELOSO, M. J. D.; FARIA, L. C.; COSTA, J. G. C.; NASCENTE, A. S.; DÍAZ, J. L. C.; CARVALHO, H. W. L.; ALMEIDA, V. M.; MELO, C. L. P.; COSTA, A. F.; POSSE, S. C. P.; SOUZA, J. F.; ABREU, A. F. B.; MAGALDI, M. C. S.; GUIMARÃES, C. M.; OLIVEIRA, J. P. BRS Notável: a medium-early-maturing, disease-resistant Carioca common bean cultivar with high yield potential. Crop Breeding and Applied Biotechnology, Viçosa, v. 12, n. 3, p. 220-223, 2012. http://dx.doi.org/10.1590/S1984-70332012000300010

RENGEL, Z.; DAMOM, P. M. Crops and genotypes differ in efficiency of potassium uptake and use. Physiologia Plantarum, v. 133, n. 4, p. 624-636, 2008. https://doi.org/10.1111/j.1399-3054.2008.01079.x

RODRIGUES, F.; MAGALHÃES, J. V.; GUIMARÃES, C. T.; TARDIN, F. D.; SCHAFFERT, R. E. Seleção de linhagens de sorgo granífero eficientes e responsivas à aplicação de fósforo. Pesquisa Agropecuária Brasileira, Brasília, v. 49, n. 8, p. 613-621, 2014. https://doi.org/10.1590/S0100-204X2014000800005

ROTILI, E. A.; FIDELIS, R. R.; SANTOS, M. M.; BARROS, H. B.; PINTO, L. C. Eficiência do uso e resposta à aplicação de fósforo de cultivares de arroz em solos de terras altas. Bragantia, Campinas, v. 69, n. 3, p. 705710, 2010. https://doi.org/10.1590/S0006-87052010000300023

SALGADO, F. H. M.; SILVA, J.; OLIVEIRA, T. C.; BARROS, H. B.; PASSOS, N. C.; FIDELIS, R. R. Eficiência de genótipos de feijoeiro em resposta à adubação nitrogenada. Pesquisa Agropecuária Tropical, Goiânia, v. 42, n. 4, p. 368-374, 2012. https://doi.org/10.1590/S1983-40632012000400007

SANT'ANA, E. V. P.; SANTOS, A. B.; SILVEIRA, P. M. Eficiência de uso de nitrogênio em cobertura pelo feijoeiro irrigado. Revista Brasileira de Engenharia Agrícola e Ambiental, Campina Grande, v. 15, n. 5, p. 458-462, 2011. https://doi.org/10.1590/S1415-43662011000500004

SOUSA, S. A.; SILVA, J.; RAMOS, D. P.; OLIVEIRA, T. C. O.; GONZAGA, L. A. M.; FIDELIS, R. R. Eficiência e resposta à aplicação de nitrogênio de genótipos de feijão comum cultivados em várzea tropical do Estado do Tocantins. Journal of Biotechnology and Biodiversity, v. 3, n. 3, p. 31-37, 2012.

https://doi.org/10.20873/jbb.uft.cemaf.v3n3.sousa

SOUSA, M. D. M.; CARVALHO, C. M.; SABINO, R. K.; LOPES, P. H.; ALCÂNTARA, V. S.; SILVESTRE, A. C. A. Efeito da adubação potássica no crescimento do feijão de corda preto. Revista Brasileira de Agricultura Irrigada, v. 7, n. 1, p. 66-73, 2013. https://doi.org/10.7127/rbai.v7n100005

TSUTSUMI, C. Y.; BULEGON, L. G.; PIANO, J. T. Melhoramento genético do feijoeiro: avanços, perspectivas e novos estudos, no âmbito nacional. Pesquisas Agrárias e Ambientais, v. 3, n. 3, p. 217-223, 2015. https://doi.org/10.14583/2318-7670.v03n03a12

VIANA, T. O.; VIEIRA, N. M. B.; MOREIRA, G. B. L.; BATISTA, R. O.; CARVALHO, S. J. P.; RODRIGUES, H. F. F. Adubação do feijoeiro cultivado no norte de Minas Gerais com nitrogênio e fósforo. Revista Ceres, Viçosa, v. 58, n. 1, p. 115-120, 2011. https://doi.org/10.1590/S0034-737X2011000100017

WANG, X.; SHEN, J.; LIAO, H. Acquisition or utilization, which is more critical for enhancing phosphorus efficiency in modern crops?. Plant Science, v. 179, n. 4, p. 302-306, 2010.

https://doi.org/10.1016/j.plantsci.2010.06.007

WHITE, P. J. Improving potassium acquisition and utilisation by crop plants. Journal of Plant Nutrition and Soil Science, v. 176, n. 3, p. 305-316, 2013. https://doi.org/10.1002/jpln.201200121

ZUCARELI, C.; PRANDO, A. M.; RAMOS JUNIOR, E. U.; NAKAGAWA, J. Fósforo na produtividade e qualidade de sementes de feijão Carioca Precoce cultivado no período das águas. Revista Ciência Agronômica, Fortaleza, v. 42, n. 1, p. 32-38, 2011. https://doi.org/10.1590/S1806-66902011000100005 